\title{
ANALISA PENGARUH BRAND REJUVENATIONTERHADAP PEMBENTUKAN PURCHASE INTENTION DENGAN BRAND IMAGESEBAGAI VARIABEL INTERVENING PADA TEPUNG PREMIKS CHESA BOX PT. ISM BOGASARI FLOUR MILLS
}

\author{
Juliana $^{1}$; Diah Dharmayanti ${ }^{1^{*}}$ \\ Program Manajemen Pemasaran, Universitas Kristen Petra \\ Jl. Siwalankerto 121-131, Surabaya \\ E-mail: m36412012@john.petra.ac.id; diah_dharmayanti@yahoo.com \\ *Korespondensi penulis
}

\begin{abstract}
Abstrak: Chesa Box Premix Flour adalah produk barang konsumsi yang diproduksi oleh PT. ISM Bogasari Flour Mills. Pada tahun 2002, Chesa Box Premix Flour telah diproduksi dan dijual dalam jumlah besar, tetapi pada tahun 2004 harus dihentikan karena alasan internal pada perusahaan. Setelah lebih dari sepuluh tahun, pada tahun 2014 Chesa Box Premix Flour diperkenalkan kembali ke pasar menggunakan strategi peremajaan merek. Penelitian ini bertujuan untuk menganalisis hubungan antara peremajaan merek, inovasi produk, dan pemosisian kembali terhadap pembentukan niat beli pada Chesa Box Premix Flour dengan menggunakan citra merek sebagai variabel intervening. Penelitian kausal ini menggunakan kuesioner dan didistribusikan ke 110 responden yang merupakan sampel penelitian ini. Hasil penelitian menunjukkan bahwa semua variabel yang terlibat dalam penelitian ini masing-masing memiliki dampak yang signifikan yang dibuktikan dengan metode pengujian hipotesis t-test atau menolak penolakan H0 jika [T-statistik] > t tabel yaitu sebesar 1,96
\end{abstract}

Kata kunci: peremanajaan merek, inovasi produk, pemosisian kemabli, image merek, minat beli

Abstract: Chesa Box Premix Flour is a product of consumer goods produced by PT. ISM Bogasari Flour Mills. In 2002, Chesa Box Premix Flour has been produced and sold in bulk, but in 2004 had to be discontinued because of the internal reason on the company. After more than ten years, in 2014 Chesa Box Premix Flour re-introduced to the market using the brand rejuvenation strategy. This research aims to analyze the relationship between brand rejuvenation, product innovation, and repositioning towards the formation of purchase intention on Chesa Box Premix Flour by using its brand image as an intervening variable. This causal research using questionnaires as a method and will be distributed to 110 respondents which is a sample of this research. The results showed that all of the variables involved in this study each have a significant impact as evidenced by the method of hypothesis testing $t$-test or reject the rejection of $H 0$ if [T-stats] > T table that is equal to 1.96 .

Keywords: Brand rejuvenation, product innovation, repositioning, brand image, purchase intention

\section{PENDAHULUAN}

Di era yang sudah modern ini, telah terjadi perubahan gaya hidup maupun dinamika sosial di masyakat, khususnya di kota-kotabesar. Mobilitas masyarakat semakin cepat karena dituntut oleh kondisi perkotaan yang semakinc anggih. Hal ini menumbuhkan kebutuhan masyarakat akan segala sesuatu yang praktis dan instant, khususnya dalam perubahan eating habit yang semula memasak dari raw material process, kini sebagian besar telah beralih ke instant food. Pada tahun 2002-2004, PT. ISM Bogasari Flour Mills memproduksi sebuah produk instant yang dikenal dengan merek "Chesa Box-Tepung Premiks CepatSaji”. Tepung Premiks Cepat Saji adalah campuran tepung terigu dengan beberapa bahan pendukung yang menghasilkan makanan, yang dapat dibuat dengan cara yang mudah dan praktis. Melihat adanya latar belakang tersebut, PT. ISM Bogasari Flour Mills melakukan sebuah inovasi dengan meremajakan kembali merek Chesa yang sudah dibiarkan 'matisuri' selama 10 tahun dengan adanya peluncuran inovasi pada produk da npenyusunan strategi repositioning yang baru seperti merevisi logo, membuat desain packaging baru, dan menambah beberapa varian rasa. Peremajaan merek "Chesa" oleh PT. ISM Bogasari Flour Mills juga dilatarbelakangi oleh kondis iadanya pertumbuhan masyarakat middle class di Indonesia yang diramalkan dari tahun 2012 hingga tahun 2020 akan terus bertambah jumlahnya. Di Indonesia, kelas menengah adalah seseorang yang termasuk dalam kategori dengan rentang penghasilan antara $\mathrm{Rp}$ 2,6 juta sampai Rp 6 juta. Boston Consulting Group (BCG) menyatakan bahwa pada 2014 kelas menengah Indonesia berjumlah 74 juta orang (sumber: BPPK Keuangan) 
yang menyatakan bahwa adanya pertumbuhan kelas menengah di Indonesia sebesar 64\%, di tahun 2012 berjumlah 41,6 juta jiwa dan 2020 berjumlah 68,2 juta jiwa. (sumber: BPPK Keuangan). Fenomena ini membuat kelas menengah Indonesia terus mengalami peningkatan yang signifikan. Kenaikan tersebut akan menyebabkan kelas menengah untuk mewujudkan keinginan-keinginan atau mimpi-mimpinya, sehingga para wirausaha dan perusahaan di Indonesia harus berusaha untuk memenuhi keinginan tersebut, oleh sebab itu hal ini merupakan peluang usaha bagi PT. ISM Bogasari Flour Mills untuk memanfaatkannya. Keseluruhan dari fenomena yang terjadi di beberapa tahun terakhir ini menjadikan PT. ISM Bogasari Flour Mills perlu lebih berkompetisi lagi mengingat posisi sebagai market leader pasar tepung nasional bukan alasan untuk memandang sebelah mata para pesaing dan tidak mengikuti kebutuhan pasar yang selalu berubah tiap zamannya. Hal ini menarik untuk diteliti guna mengetahui bagaimana merek Chesa yang muncul kembali di tahun 2014 ini menghadapi pasar yang semakin ketat dengan memperkenalkan strategi peremajaan mereknya yang baru.

Berdasarkan fenomena diatas dapat disimpulkan beberapa masalah penelitian sebagai berikut:

1. Apakah brand rejuvenation berpengaruh terhadap product innovation tepung premiks Chesa Box?

2. Apakah brand rejuvenation berpengaruh terhadap repositioning tepung premiks Chesa Box?

3. Apakah brand rejuvenation berpengaruh terhadap brand image tepung premiks Chesa Box?

4. Apakah product innovation berpengaruh terhadap brand image tepung premiks Chesa Box?

5. Apakah repositioning berpengaruh terhadap brand image tepung premiks Chesa Box?

6. Apakah productinnovation berpengaruh terhadap purchase intention tepung premiks Chesa Box?

7. Apakah repositioning berpengaruh terhadap purchase intention tepung premiks Chesa Box?

8. Apakah brand image berpengaruh terhadap purchase intention tepung premiks Chesa Box?

\section{KAJIAN PUSTAKA}

\section{Brand Rejuvenation}

Persaingan yang ketat, kondisi pasar yang tidak menentu, dan faktor sosial maupun gaya hidup sering menjadi alasan mengapa sebuah merek harus selalu mengikuti perkembangan zaman, baik dengan mengubah beberapa aspek merek sebagian atau secara total, bahkan meremajakan mereknya. Merek yang tidak menghasilkan lagi keuntungan pada akhirnya harus dihadapkan ke dua pilihan, yaitu diberhentikan atau dipertahankan.Jika pilihannya adalah dipertahankan, maka peremajaan merek dapat menjadi salah satu alternatifnya.

Pengertian peremajaan merek atau bisa disebut brand rejuvenation dikemukakan oleh beberapa peneliti, salah satunya oleh Babu (2006) yang menyamakan revitalisasi merek dengan peremajaan merek dan menganggap itu semacam pembenahan dari merek, proses yang juga mencakup regenerasi identitas merek.

Pada dasarnya, siklus kehidupan merek memiliki empat tahap dasar, yaitu introduction, growth, mature, decline. Dalam penelitiannya, Babu (2006) menganggap strategi peremajaan merek dapat menjadi formula yang berlaku untuk merek yang berada di dua tahap pertama juga. Mereka perlu dibawa ke tahap tiga atau empat. Dalam istilah sederhananya lagi, peremajaan merek adalah upaya untuk membawa merek yang tidak bisa menghasilkan uang menjadi dapat menghasilkan uang, dengan positioning baru atau strategi komunikasi.

Sebuah merek yang mungkin telah gagal maupun yang sudah tidak diterima lagi oleh pasar, sebenarnya memiliki lebih kecil resiko daripada harus memperkenalkan merek baru ke pasar. Hal ini dikarenakan merek yang sudah pernah ada di pasar: (Berenson dan Jackson, 1994)

1. Sudah pernah melakukan promosi untuk pengenalan produk,

2. Sudah memiliki channel distribution sebagai pemasoknya,

3. Menghemat product development cost,

4. Menghemat biaya peralatan.

5. Masih memiliki sebagian kecil dari market share karena adanya old user.

Dalam pengaplikasiannya, proses peremajaan merek dapat dicapai melalui dua aktivitas utama, yaitu dengan adanya inovasi dan repositioning merek. Kedua aktivitas utama tadi sebenarnya tidaks aling berkaitan tetapi sering terlihat beroperasi secara bersama-sama, serta membutuhkan adaptasi (Groucutt, 2006).

\section{Product Innovation}

Secara umum, banyak yang mengenal istilah inovasi sendiri sebagai sesuatu yang benar-benar baru, bahkan sebagai suatu penciptaan yang besar, hal tersebut tidaklah salah, namun sebenarnya inovasi sendiri menurut para ahli bisa disebut sebagai suatu pengembangan juga dari sesuatu yang telah ada. 
Gopalakrishnan dan Damanpour (1997) berpendapat inovasi produk dapat didefinisikan sebagai penciptaan produk baru dari bahan baru atau perubahan produk yang ada untuk memenuhi kepuasan pelanggan (versi pengembangan dari produk sebelumnya). Tuntutan pasar akan kebutuhan-kebutuhan yang baru, lebih canggih, lebih menarik, dan lebih efisiensi biaya terkadang menjadi faktor mengapa suatu produk sebaiknya melakukan sebuah inovasi. Oleh sebab itu, Groucutt (2006) mengatakan bahwa inovasi tidak selalu harus berarti perubahan yang besar dan bisa menjadi langkah kecil untuk pengembangan suatu produk.Inovasi produk sendiri terkadang dilakukan untuk pengembangan suatu produk agar produk tersebut memiliki nilai jual yang lebih tinggi.

Kanagal (2015) mengatakan bahwa sebuah produk adalah kombinasi satu atau lebih dari (a) bahan (b) atribut (c) manfaat (d) keuntungan (e) fitur (f) fungsi (g) kinerja (h) model bisnis (i) pengalaman penggunaan $(j)$ pengalaman konsumsi, sehingga inovasi yang terwujud dalam produk seperti yang didefinisikan disebut sebagai inovasi produk. Sebuah inovasi pada produk saat ini menjadi hal yang sering dilakukan banyak perusahaan maupun organisasi untuk menarik perhatian pasar juga bahwa perusahaan atau organisasi tersebut masih menunjukkan eksistensi mereka.

Sciffman dan Kanuk (2010) membagi inovasi menjadi tiga tipe, yaitu:

1. Continuous innovation, yang memodifikasi produk yang ada, biasanya inovasi tipe ini bersifat evolusioner karena hanya memunculkan perubahan kecil untuk kepentingan positioning sebuah produk, perluasan lini, atau untuk menghilangkan kebosanan pelanggan.

2. Dynamically continuous innovation, mengacu pada perubahan yang dapat mengubah perilaku atau cara seseorang dalam melakukan sesuatu.

3. Discontinuous innovations, melakukan penemuan besar yang pertama kali ada dan dapat mengubah cara hidup orang banyak.

\section{Repositioning}

Strategi marketing yang wajib perencanaannya diawal salah satunya adalah bagaimana perusahaan ingin memposisikan merek produknya di mata konsumen atau sering disebut sebagai strategi positioning. Positioning mencoba untuk mendapatkan posisi di benak konsumen serta untuk mendeferensiasikan diri dari pesaing-pesaingnya. Hal ini terutama penting dalam kondisi dan di pasar dengan mobilitas kompetitif yang tinggi.
Kotler (2003) mengatakan bahwa salah satu langkah yang perlu dilakukan dalam melakukan positioning, yaitu mengidentifikasi adanya keunggulan kompetitif (competitive advantage) dalam perusahaan. Untuk mendapatkannya, maka perusahaan harus melakukan diferensiasi melalui inovasi terhadap bauran pemasaran (marketing mix).

Ketika positioning merek telah ketinggalan atau tidak sesuai dengan kondisi pasar, maka perusahaan biasanya akan melakukan strategi selanjutnya yaitu repositioning atau melakukan positioning ulang. Keller (2013) mengatakan repositioning dilakukan untuk mengubah citra perusahaan sehingga menempati tempat baru dan nilai dalam benak konsumen. Di sisi lain repositioning juga menuntut sebuah merek untuk membuat sesuatu sebagai pembeda dengan kompetitor.

\section{Brand Image}

Citra merek atau biasa disebut brand image telah lama diakui sebagai salah satu aspek yang penting di pemasaran dan beberapa ahli yang menyamakan brand image sebagai assosiation (Kapferer, 2008, p. 11). "Brand image is on the receiver's side" (Kapferer, 2008, p.174) menegaskan kembali bahwa citra merek adalah gambaran merek dari sisi penerima atau bisa disebut konsumen, bukan dari sisi perusahaan/internal. Salah satu ahli juga mendefinisikannya sebagai persepsi konsumen dan preferensi untuk merek, yang diukur oleh berbagai jenis asosiasi merek yang ada di memori konsumen (Keller, 2013).

Dimensi-dimensi brand image menurut Keller (2013) tergantung oleh pembentukan faktor-faktor berikut:

1. Strength of Brand Association

Dimensi ini menceritakan mengenai kekuatan sebuah merek di pikiran konsumen. Kekuatan sebuah merek juga dipengaruhi oleh seberapa banyak informasi yang masuk ke konsumen dan bagaimana informasi tersebut dipertahankan di dalam pikiran konsumen.

\section{Favourability of Brand Association}

Dimensi ini mengukur apakah sebuah brand disukai atau tidak disukai oleh konsumen, dengan itu dapat dilihat apakah konsumen yakin dengan merek tersebut (convenient, reliable, effective, efficient, colorful).

3. Uniqueness of Brand Association

Dimensi ini menceritakan bagaimana sebuah perusahaan memiliki nilai lebih atau keunggulan dari para pesaingnya, hal ini penting karena dapat membentuk memori yang kuat di benak konsumen sebagai pembeda dengan merek lain. 


\section{Purchase Intention}

Purchase intention atau minat beli adalah jenis pengambilan keputusan yang mempelajari alasan untuk membeli merek tertentu oleh konsumen (Shah et al., 2012). Sebuah minat akan suatu hal timbul karena beberapa proses yang terjadi di pikiran para konsumen, yang sebenarnya merupakan sebuah proses yang dipengaruhi oleh banyak faktor yang cukup sensitif, tergantung apa kebutuhan yang diperlukan konsumen. Oleh sebab itu, minat beli adalah proses yang kompleks dan rumit dimana banyak terjadi pertimbangan yang merupakan langkah awal konsumen mengonsumsi suatu produk. Penelitian yang telah dilakukan oleh Gogoi (2013) menyimpulkan bahwa minat beli mungkin dapat berubah karena terpengaruh oleh harga, kualitas, maupun value, terutama ketika proses pembelian berlangsung.

Dalam penelitian oleh Jaafar et al., (2012), menggabungkan beberapa kesimpulan penelitian dari Chaniotakis et al., (2010); Beneke (2010); Liljander et al., (2009) bahwa 'harga yang dirasakan', 'kemasan', 'iklan', 'citra toko', 'persepsi kualitas', 'risiko yang dirasakan', 'nilai yang dirasakan', 'kepercayaan pada produk', 'keakraban', 'dirasakan situasi ekonomi', terkait dengan niat beli konsumen terhadap produk makanan private label.

Selain itu, menurut Sciffman dan Kanuk (2007), terdapat indikator-indikator minat beli, yaitu jika pelanggan:

1. Tertarik untuk mencari informasi mengenai produk.

2. Mempertimbangkan untuk membeli.

3. Tertarik untuk mencoba.

4. Ingin mengetahui produk.

5. Ingin membeli produk.

\section{Kerangka Konseptual}

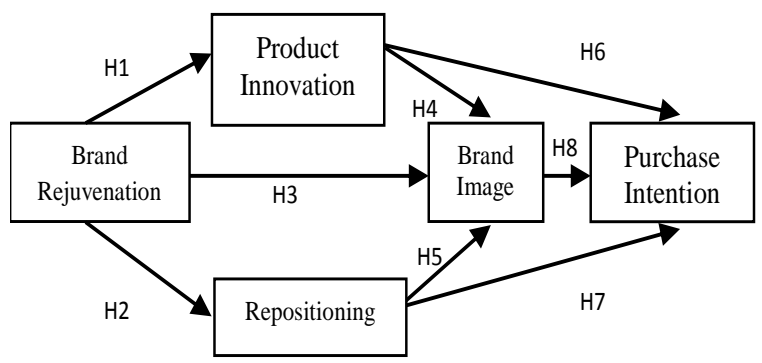

Gambar 1. Kerangka Konseptual

\section{Hipotesa}

H1: Diduga brand rejuvenation berpengaruh terhadap product innovation

$\mathrm{H} 2$ : Diduga brand rejuvenation berpengaruh terhadap repositioning

H3: Diduga brand rejuvenation berpengaruh terhadap brand image

H4: Diduga product innovation berpengaruh terhadap brand image

H5: Diduga repositioning berpengaruh terhadap brand image

H6: Diduga product innovation berpengaruh terhadap purchase intention

H7: Diduga repositioning berpengaruh terhadap purchase intention

H8: Diduga brand image berpengaruh terhadap purchase intention

\section{METODE PENELITIAN}

\section{Jenis Penelitian}

Jenis penelitian yang akan digunakan dalam penelitian ini adalah penelitian kausal. Penelitian ini menggunakan metode kuantitatif yang penyajiannya berupa angka-angka dan keluasan informasi (bukan kedalaman). Melalui metode ini pula akan digunakan populasi yang luas dengan data yang terbatas, sehingga data atau hasil riset dianggap merupakan representasi dari seluruh populasi (Sugiyono, 2010).

\section{Populasi dan Sampel}

Populasi penelitian ini adalah pengguna tepung premiks merek Chesa Box dan/atau orang yang sedang berbelanja Chesa Boxdi Giant Hypermarket Surabaya.

\section{Teknik Pengambilan Sampel}

Metode pengambilan sampel yang digunakan adalah non probability sampling yaitu purposive sampling yaitu metode dimana pengambilan sampel didasarkan pada pertimbangan peneliti melalui seleksi khusus.

\section{Definisi Operasional Variable}

Definisi operasional yang digunakan dalam penelitian ini terdiri dari 5 variabel, yaitu: 


\section{Brand Rejuvenation (X)}

Brand rejuvenation sebagai suatu strategi yang digunakan perusahaan untuk mengidentifikasi identitas merek di pasar, lalu menilai jika pasar sudah jenuh atau sudah tidak tertarik pada produk, maka peremajaan merek merupakan salah satu strategi yang dapat dilakukan.

\section{Product Innovation (Y1)}

Dalam penelitian ini, peneliti mendefinisikan product innovation sebagai suatu proses penambahan/ modifikasi pada produk guna meningkatkan kualitas produk suatu merek perusahaan, contohnya dengan adanya penambahan komposisi, ide dan manfaat yang baru ke dalam produk yang dampaknya akan menjadi pembeda dari kompetitor-kompetitornya.

\section{Repositioning(Y2)}

Repositioning adalah strategi ulang perusahaan dalam memposisikan diri dengan mengubah beberapa aspek tetapi posisi dasar merek masih digunakan untuk menciptakan image yang berbeda diantara pesaing-pesaingnya dimana pelaksanaannya melalui perencanaan marketing mix yang baru dan berpengaruh di pikiran konsumen.

ikut:

Repositioning diukur dengan beberapa hal ber-

1. Produk, adalah sesuatu yang ditawarkan dan diperjualbelikan guna memenuhi kebutuhan dan keinginan konsumen/pasar.

2. Harga, adalah satuan nilai tukar suatu produk yang dalam penetapannya disesuaikan dengan strategi perusahaan/organisasi dan target pasarnya.

3. Distribusi, adalah suatu aktivitas pemasaran guna menyampaikan suatu produk dari produsen ke konsumen yang mencangkup efektivitas dan pemilihan tempat aktivitas penjualan dimana konsumen dapat menemukan produk tersebut.

4. Promosi, adalah suatu aktivitas pemasaran yang diselenggarakan guna memberi informasi produk guna menarik para calon konsumen untuk membelinya.

\section{Brand Image (Y3)}

Brand Image adalah suatu persepsi konsumen yang menggambarkan bagaimana merek tersebut di pikiran konsumen berdasarkan asosiasi-asosiasi yang terbentuk. Brand Image dapat diukur berdasarkan:

1. Strength of Brand Association adalah dimensi yang mengukur citra sebuah merek dengan melihat apa yang menjadi kekuatan merek tersebut yang diketahui oleh konsumen.

2. Favorability of Brand Association adalah dimensi yang mengukur seberapa konsumen menyukai atribut dan manfaat yang ditawarkan oleh merek tersebut.
3. Uniqueness of Brand Association adalah dimensi yang mengukur bagaimana respon konsumen terhadap nilai lebih (keunggulan bersaing) yang ditawarkan suatu merek.

\section{Purchase Intention (Z)}

Purchase Intention atau minat beli adalahsuatu proses perilaku konsumen dimana konsumen memiliki ketertarikan untuk mencoba, lalu merekomendasikan dan bahkan membeli ulang merek.

\section{Teknik Analisa Data}

Peneliti menggunakan analisis SEM-PLS yang diterapkan dalam penelitian ini, yang tahap-tahap-nya adalah:

1. Tahap evaluasi outer model meliputiuji validitas (kovergen dan diskriman) dan uji reliabilitas.

2. Tahap evaluasi inner modeldengan melihat $\mathrm{R}^{2}$ untuk konstruk laten dependen, Stone-Geisser $Q$ square test untuk predictive relevance (Ghozali, 2011) dan juga melihat besarnya koefisien parameter jalur strukturalnya.

3. Merumuskan hipotesis penelitian dengan uji statistik untuk menentukan daerah penolakan $\mathrm{H}_{0}$ sehingga dapat diperoleh kesimpulan hasil hipotesis penelitian. Daerah penolakan $\mathrm{H}_{0}$ atau Tolak $\mathrm{H}_{0}$ jika [T-statistik] > $\mathrm{T}_{\text {Tabel }}$ yaitu sebesar 1,96 dan original sample estimate positif.

\section{ANALISA DAN PEMBAHASAN}

Adanya brand rejuvenation yang dilakukan oleh PT. Bogasari melalui product innovation dan repositioning ternyata terbukti mampu mendongkrak brand image pada tepung Chesa di pasaran industry tepung premix di Indonesia. Meskipun secara riel, adanya brand image yang meningkat tidak dapat secara instant meningkatkan purchase intention pengguna tepung di marketplace.

\section{Outer Model}

\section{Convergent Validity}

Tabel 1. Uji Convergent Validity

\begin{tabular}{c|c}
\hline Variabel & AVE \\
\hline Brand Image & 0.645 \\
\hline Brand Rejuvenation & 0.711 \\
\hline Product Innovation & 0.653 \\
\hline Purchase Intention & 0.767 \\
\hline Repositioning & 0.630 \\
\hline
\end{tabular}

Untuk memeriksa nilai convergent validity, diperlukan evaluasi Average Variance Extracted (AVE) 
setiap variabel laten. Nilai AVE harus lebih besar dari angka 0,5 untuk dapat memastikan bahwa tiap variabel memiliki parameter convergent validity yang layak digunakan. Tabel 1 mendemonstrasikan bahwa keseluruhan variabel yang digunakan pada penelitian ini memiliki convergent validity yang layak.

\section{Discriminant Validity}

Tabel 2.Uji Discriminant Validity

\begin{tabular}{|c|c|c|c|c|c|c|c|}
\hline \multirow[b]{2}{*}{ Variabel } & \multirow[b]{2}{*}{ AVE } & \multirow{2}{*}{$\begin{array}{l}\text { Akar } \\
\text { AVE }\end{array}$} & \multicolumn{5}{|c|}{ Korelasi } \\
\hline & & & $\begin{array}{l}\text { Brand } \\
\text { Image }\end{array}$ & $\begin{array}{c}\text { Brand } \\
\text { Rejwenation }\end{array}$ & $\begin{array}{c}\text { Product } \\
\text { Imnovation }\end{array}$ & $\begin{array}{l}\text { Purchase } \\
\text { Intention }\end{array}$ & Repositioning \\
\hline Brand Image & 0.645 & 0.803 & 1.000 & & & & \\
\hline Brand Rejuvenation & 0.711 & 0.843 & 0.756 & 1.000 & & & \\
\hline Product Innovation & 0.653 & 0.808 & 0.755 & 0.640 & 1.000 & & \\
\hline Purchase Intention & 0.767 & 0.876 & 0.782 & 0.646 & 0.710 & 1.000 & \\
\hline Repositioning & 0.630 & 0.794 & 0.804 & 0.626 & 0.645 & 0.736 & 1.000 \\
\hline
\end{tabular}

Melalui tabel 2 dapat dilihat bahwa akar pangkat AVE variabelbrand experience, brand trust, customer satisfaction, customer intimacy dan customer loyalty memiliki hasilyang valid. Melalui hasil tersebut dilihat juga hubungan antar variable yang sebagian besar bersifat valid.

\section{Composite Reliability}

Tabel 3.Uji Composite Reliability

\begin{tabular}{c|c}
\hline Variabel & Composite Reliability \\
\hline Brand Image & 0.942 \\
\hline Brand Rejuvenation & 0.881 \\
\hline Product Innovation & 0.849 \\
\hline Purchase Intention & 0.908 \\
\hline Repositioning & 0.953 \\
\hline
\end{tabular}

Tabel 3 menunjukkan bahwa keseluruhan variabel laten dalam penelitian memiliki nilai composite reliability diatas 0,7 , sehingga dapat disimpulkan bahwa keseluruhan variabel memiliki levelconsistency reliability yang tinggi.

\section{Path Coefficient dan R-Square}

Evaluasi path coefficient digunakan untuk menunjukkan seberapa kuat efek atau pengaruh variabel independen kepada variabel dependen. Sedangkan coefficient determination digunakan untuk mengukur seberapa banyak variabel endogen dipengaruhi oleh variabel lainnya. Didalam penelitian, nilai $\mathrm{R}^{2}$ diatas 0,75 keatas dikategorikan substansial, $0,50-0,75$ artinya sedang, dan 0,25-0,50 artinya lemah.

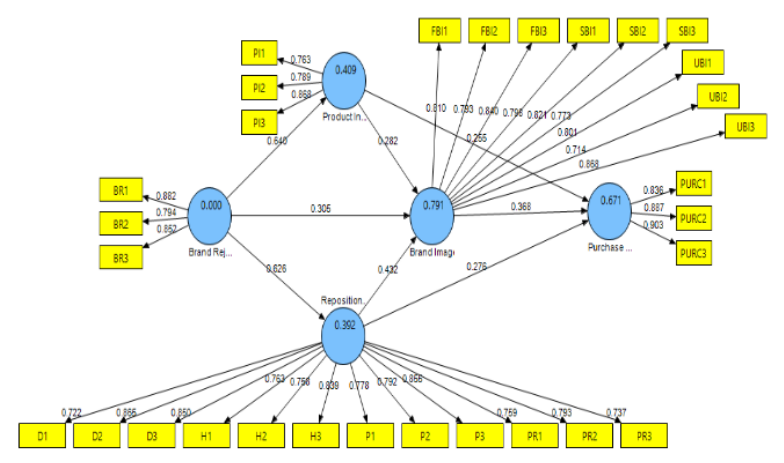

Gambar 2. Path Coefficient

Gambar 2 menunjukkan bahwa nilai path coefficient masing-masing variabel adalah sebagi berikut:

1. Path coefficient antara Brand Rejuvenation terhadap Product Innovation sebesar 0,640.

2. Path coefficient antara Brand Rejuvenation terhadap Repositioning sebesar 0,626.

3. Path coefficient antara Brand Rejuvenation terhadap Brand Image sebesar 0,305.

4. Path coefficient antara Product Innovation terhadap Brand Image sebesar 0,282.

5. Path coefficient antara Repositioning terhadap Brand Image sebesar 0,432.

6. Path coefficient antara Product Innovation terhadap Purchase Intention sebesar 0,255.

7. Path coefficient antara Repositioning terhadap Purchase Intention sebesar 0,276.

8. Path coefficient antara Brand Image terhadap Purchase Intention sebesar 0,368.

Tabel 4. $R$ Square

\begin{tabular}{c|c}
\hline Variabel & R Square \\
\hline Product Innovation & 0.409 \\
\hline Repositioning & 0.392 \\
\hline Brand Image & 0.791 \\
\hline Purchase Intention & 0.671 \\
\hline
\end{tabular}

Pada model PLS, penilaian goodness of fit diketahui dari nilai $\mathrm{Q}^{2}$ guna mengukur apakah model memiliki predictive relevance. Nilai $\mathrm{Q}^{2}$ memiliki arti yang sama dengan koefisien determinasi (R-Square) pada analisis regresi, dimana semakin tinggi RSquare, maka model dapat dikatakan semakin fit dengan data. Berdasarkan nilai R Square pada Tabel 4 dapat dihitung nilai $Q^{2}$ sebagai berikut:

$1-(1-0.409) \times(1-0.392) \times(1-0.791) \times(1-0.671)$ $=0.975$

Dari hasil perhitungan diketahui nilai $\mathrm{Q}^{2}$ sebesar 0.975 , artinya besarnya keragaman dari data penelitian yang dapat dijelaskan oleh model struktural 
adalah sebesar $97.5 \%$, sedangkan $2.5 \%$ sisanya dijelaskan oleh faktor lain di luar model. Berdasarkan hasil ini, model struktural pada penelitian dapat dikatakan telah memiliki goodness of fit yang baik.

\section{T-Statistics dan Uji Hipotesis}

Nilai T-statistics diperoleh dari prosedur bootstrapping, yang digunakan untuk menarik kesimpulan pada uji hipotesis. Nilai T-statistics dengan level signifikansi 5\% menjelaskan bahwa inner model akan signifikan jika nilai T-statistics lebih besar dari 1,96.

Tabel 5.T-Statistics

\begin{tabular}{c|l|c|c|c}
\hline \multicolumn{2}{c|}{ Hipotesis } & Koefisien & $\mathrm{t}$ Statistik & Keterangan \\
\hline 1 & Brand Rejuvenation $>$ Product Innovation & 0.640 & 11.155 & Diterima \\
\hline 2 & Brand Rejuvenation $>$ Repositioning & 0.626 & 10.199 & Diterima \\
\hline 3 & Brand Rejuvenation $>$ Brand Image & 0.756 & 4.359 & Diterima \\
\hline 4 & Product Innovation $>$ Brand Image & 0.282 & 4.368 & Diterima \\
\hline 5 & Repositioning $>$ Brand Image & 0.432 & 4.518 & Diterima \\
\hline 6 & Product Innovation $>$ Purchase Intention & 0.358 & 3.254 & Diterima \\
\hline 7 & Repositioning $>$ Purchase Intention & 0.434 & 2.621 & Diterima \\
\hline 8 & Brand Image $>>$ Purchase Intention & 0.368 & 2.972 & Diterima \\
\hline
\end{tabular}

\section{Pembahasan}

\section{Brand Rejuvenation terhadap Product Innovation}

Hasil penelitian menunjukkan bahwa brand rejuvenation memiliki pengaruh yang signifikan terhadap product innovation produk Tepung Premiks Chesa Box PT. ISM Bogasari FM. Hasil ini sesuai dengan teori dari Groucutt (2006) yang menggolongkan product innovation sebagai salah satu aktivitas utama dari brand rejuvenation. Selanjutnya, hasil penelitian ini juga sesuai dengan penelitian yang dilakukan oleh Thomas dan Kohli (2009) yang menjelaskan bahwa aktivitas peremajaan merek seharusnya dilaksanakan bersama dengan adanya inovasi produk pula.

Semakin sering Tepung Premiks Chesa Box melakukan product innovation seperti contohnya dengan mengembangkan fitur-fitur produk yang belum dimiliki pesaing-pesaingnya, makahal tersebut akan semakin pula mendukung aktivitas keberhasilan dari brand rejuvenation yang dilakukan PT. ISM Bogasari FM.

\section{Brand Rejuvenation terhadap Repositioning}

Hasil penelitian menunjukkan bahwa brand rejuvenation memiliki pengaruh yang signifikan terhadap repositioning produk Tepung Premiks Chesa Box PT. ISM Bogasari FM. Hasil ini sesuai dengan teori dari Babu (2006) dan Groucutt (2006) yang mengelompokkan aktivitas repositioning sebagai salah satu bagian dari aktivitas brand rejuvenation. Selain itu, hasil penelitian ini sesuai dengan penelitian yang telah diteliti sebelumnya oleh Kolbl et al., (2015) dari studi kasus merek Argeta.

Kesimpulannya, dari keempat dimensi repositioning, diketahui bahwa dimensi yang sudah cukup sukses adalah dimensi produk, dimana dimensi ini memiliki hasil penelitian signifikan yang tertinggi, sedangkan dimensi distribusi dan promosi masih perlu ditingkatkan kembali karena memiliki respon yang cukup rendah daripada indikator repositioning lainnya.

\section{Brand Rejuvenation terhadap Brand Image}

Hasil penelitian menunjukkan bahwa brand rejuvenation memiliki pengaruh yang signifikan terhadap brand image produk Tepung Premiks Chesa Box PT. ISM Bogasari FM. Hasil ini sesuai dengan teori dari Babu (2006) yang mengatakan bahwa aktivitas brand rejuvenation dapat mempengaruhi bagaimana konsumen mempresepsikan suatu brand di pikiran mereka serta sesuai dengan teori oleh Keller (2013) bahwa setiap asosiasi-asosiasi brand image akan berpengaruh terhadap persepsi konsumen. Ketika sebuah merek diremajakan, asosiasi-asosiasi baru dapat terbentuk, bahkan dari sana PT. ISM Bogasari FM dapat mengembangkan bagian mana yang disukai oleh konsumen serta menghindari bagian mana yang tidak disukai. Hal ini dapat menjadi pengukuran yang baik bila aktivitas peremajaan merek yang dilakukan masih belum maksimal atau sebaliknya.

Tepung Premiks Chesa Box memiliki brand image yang cukup baik di konsumen. Dimensi yang memiliki nilai tertinggi adalah dimensi unique of brand association dan terendah diperoleh pada dimensi strength of brand association. Oleh sebab itu, hasil penelitian ini menilai bahwa PT. ISM Bogasari FM harus lebih meningkatkan strength of brand association, dimana para konsumen secara mayoritas belum merasakan bahwa Tepung Premiks Chesa Box dapat mempengaruhi gaya hidup mereka.

\section{Product Innovation terhadap Brand Image}

Hasil penelitian menunjukkan bahwa product innovation memiliki pengaruh yang signifikan terhadap brand image produk Tepung Premiks Chesa Box PT. ISM Bogasari FM. Hasil ini sesuai dengan teori dan penelitian yang dilakukan oleh Liu et al., 
(2014) bahwa jika brand image suatu produk tinggi, maka penerimaan konsumen akan inovasi juga ikut tinggi. Selain itu, Hanaysha et al., (2014) dan Shiau (2014) menyimpulkan juga pada hasil penelitian mereka bahwa inovasi produk memiliki dampak positif yang signifikan pada citra merek.

Tepung Premiks Chesa Box PT. ISM Bogasari FM telah cukup berhasil dalam menyampaikan pesan merek dengan menciptakan inovasi produk yang terbukti dengan hasil penelitian bahwa pembuatan kue menjadi lebih mudah dengan adanya penambahan bahan pelengkap dimana hal ini menjadikan Tepung Premiks Chesa Box PT. ISM Bogasari FM berbeda daripada tepung premiks lainnya.

\section{Repositioning terhadap Brand Image}

Hasil penelitian menunjukkan bahwa repositioning memiliki pengaruh yang signifikan terhadap brand image produk Tepung Premiks Chesa Box PT. ISM Bogasari FM. Hasil ini sesuai dengan teori Kapferer (2009) dan Kotler (2007) yang mendukung bahwa aktivitas repositioning memiliki keterkaitan yang erat dengan penciptaan brand image di pikiran konsumen.

PT. ISM Bogasari diharapkan dapat mengembangkan lagi beberapa dimensi repositioning yang memiliki nilai terendah, yaitu pada dimensi promosi sehingga pembentukan brand image dapat naik dan kedepannya meningkatkan daya jual Tepung Premiks Chesa Box.

\section{Product Innovation terhadap Purchase Intention}

Hasil penelitian menunjukkan bahwa product innovation memiliki pengaruh yang signifikan terhadap purchase intention konsumen pada produk Tepung Premiks Chesa Box PT. ISM Bogasari FM. Hasil ini sesuai dengan hasil penelitian yang dilakukan sebelumnya juga oleh Uliana (2012) serta Suroso dan Iriani (2014) dimana produk yang diinovasi dapat menimbulkan minat konsumen dalam mencoba, merasakan, bahkan membeli..

Tepung Premiks Chesa Box PT. ISM Bogasari FM telah berinovasi dengan cukup baik, sehingga para konsumen memiliki minat untuk mencoba dan bahkan membeli kembali Tepung Premiks Chesa Box PT. ISM Bogasari FM.

\section{Repositioning terhadap Purchase Intention}

Hasil penelitian menunjukkan bahwa product innovation memiliki pengaruh yang signifikan terhadap purchase intention konsumen pada produk Tepung Premiks Chesa Box PT. ISM Bogasari FM. Hasil ini sesuai dengan hasil penelitian yang dilakukan oleh Jaafar (2012). Memposisikan ulang sebuah merek dengan baik dapat menimbulkan minat beli bahkan mendapatkan konsumen baru.Dimensi produk pada variabel repositioning menunjukkan bahwa konsumen merasa membutuhkan produk tepung premiks, sehingga PT. ISM Bogasari sudah tepat dalam mengeluarkan produk Tepung Premiks Chesa Box.

\section{Brand Image terhadap Purchase Intention}

Hasil penelitian menunjukkan bahwa repositioning memiliki pengaruh yang signifikan terhadap brand image produk Tepung Premiks Chesa Box PT. ISM Bogasari FM. Hasil ini sesuai dengan hasil penelitian yang pernah dilakukan oleh Wang dan Tsai (2014) dan Khan et al., (2015) mengenai hubungan antara brand image dalam menumbuhkan purchase intention. Semakin baik sebuah brand image baik dari segi intrinsik maupun eksintrik, maka konsumen akan memiliki minat mencoba bahkan membeli (Zeithaml, 1988).

Minat konsumen untuk mencoba serta membeli Tepung Premiks Chesa Box PT. ISM Bogasari FM sudah cukup baik, namun konsumen masih merasa enggan merekomendasikan Tepung Premiks Chesa Box PT. ISM Bogasari FM ke orang lain, hal ini dapat berkaitan dengan dimensi brand image yaitu strength of brand association dimana konsumen merasa Tepung Premiks Chesa Box PT. ISM Bogasari FM belum terlalu dapat mempengaruhi gaya hidup, sehingga keengganan merekomendasikan produk dirasakan oleh para konsumen.

\section{KESIMPULAN DAN SARAN}

\section{Kesimpulan}

Berdasarkan hasil penelitian maka dapat disimpulkan bahwa:

1. Brand rejuvenation memiliki pengaruh yang positif terhadap product innovation

2. Brand rejuvenation memiliki pengaruh yang positif terhadap repositioning, namun hasil dari repositioning masih belum sesuai dengan harapan PT. ISM Bogasari Flour Mills yang bertujuan menembak segmen middle class karena brand rejuvenation baru saja dilakukan.

3. Brand rejuvenation memiliki pengaruh yang positif terhadap brand image. Hasil penelitian 
menunjukkan bahwa persepsi konsumen dari dimensi strength, favourability, dan unique of brand association sama-sama memiliki persepsi yang cukup baik, namun untuk nilai dimensi strength of brand association masih belum optimal karena peremajaan Chesa Box baru saja dilakukan dari periode 2014 hingga 2015 ini.

4. Product innovation memiliki pengaruh yang positif terhadap brand image. Melalui penelitian yang dilakukan, keterkaitan ini yang memperkuat bahwa product innovation yang dilakukan PT. ISM Bogsasari Flour Mills membuat para konsumen memiliki persepsi Chesa Box adalah produk tepung premiks yang mudah dan praktis karena ada penambahan bahan pelengkap di dalam kemasan Chesa Box.

5. Repositioning memiliki pengaruh yang positif terhadap brand image. Hasil penelitian secara deskriptif menunjukkan bahwa ketika PT. ISM Bogasari melakukan repositioning, PT. ISM Bogasari Flour Mills ingin Chesa Box dipersepsikan sebagai produk yang mudah dan praktis.

6. Product innovation memiliki pengaruh yang positif terhadap purchase intention. Hasil penelitian menunjukkan bahwa product innovation dari Chesa Box yang menjadi salah satu alasan mengapa para konsumen memiliki minat membeli Chesa Box melalui penambahan bahan pelengkap pada kemasan yang membuat konsumen mudah dalam membuat kue.

7. Repositioning memiliki pengaruh yang positif terhadap purchase intention yang dibuktikan dengan nilai t-hitung sebesar 2.621, namun dari segi promosi masih kurang optimal karena adanya ketidakseimbangan antara promosi ATL (Above The Line) dengan BTL (Below The Line) karena hasil penelitian menunjukkan bahwa nilai rata-rata lebih tinggi atau lebih efektif dilakukan promosi secara BTL (Below The Line).

8. Brand image memiliki pengaruh yang positif terhadap purchase intention. Para konsumen merasa bahwa favourability dan uniqueness of brand association dari Chesa Box yang memiliki nilai rata-rata tertinggi mampu untuk memunculkan minat beli konsumen, namun dampaknya masih kurang optimal karena strength of brand association masih memiliki pengaruh yang rendah dalam mengubah gaya hidup konsumen secara keseluruhan.

\section{Saran}

Berdasarkan kesimpulan di atas, maka saran yang dapat diberikan adalah sebagai berikut:
1. PT. ISM Bogasari Flour Mills sebaiknyaselain menciptakan ide promosi yang menarik untuk Chesa Box, juga menambah frekuensi promosinya, seperti pengadaan customer experience rutin setiap bulan dengan ide yang menarik, baik dari media sosial maupun event-event.

2. Keseluruhan dari semua variabel penelitian menunjukkan hasil yang positif, namun pengembangan dari tepung premiks Chesa Box masih diperlukan khususnya pada strategi repositioning yaitu bidang distribusi dengan memeratakan pola distribusi seluruh varian rasa dengan pemilihan tempat distribusi yang terfokus agar dapat mengoptimalkan persepsi strength of brand association serta meningkatkan minat konsumen ke minat ulang untuk membeli, mengingat peremajaan Chesa Box baru saja dilakukan setelah kurang lebih 10 tahun yang lalu discontinued.

\section{DAFTAR PUSTAKA}

Babu, V. (2006).Issues in Brand Rejuvenation Strategies. Retrieved from http://www.expectad. com/white_paper/Brand_Rejuvenation_Expect_ Advertising_Inc.pdf.

Beneke, Justin. (2010). Consumer perceptions of private label brands within the retail grocery sector of South Africa. African Journal of Business Management. 4(2), pp. 203-220.

Berenson, C., Iris Mohr-Jackson. (1994). Product Rejuvenation: A Less Risky Alternative to Product Innovation. Business Horizon. NovemberDecember 1994, p. 51-57.

BPPK, Keuangan. (2014). [available at: http://www. bppk.kemenkeu.go.id/]

Chaniotakis et al., (2010).Consumers' intentions of buying own-label premium food products. Journal of Product and Brand Management, pp. 327-344.

Ghozali, I. (2011). Structural Equation Modeling Metode Alternatif dengan Partial Least Square PLS, Edisi 3: Semarang. Badan Penerbit UNDIP.

Gogoi, Bidyut Jyoti (2013). Study of Antecedents of Purchase Intention and Its Effect on Brand Loyalty of Private Label Brand of Appeal. International Journal of Sales and Marketing. 3(2), pp. 73-86.

Gopalakrishnan, S., J. Damanpour (1997).A Review of Innovation Research in Economics, Sociology, and Technology Management. Omega, International Journal Science. 25(I), pp. 15-28. 
Groucutt, Jonathan, (2006). The life, death and resuscitation of brands. Handbook of Business Strategy, 7(1), pp. 101-106.

Hanaysha, Jalal, Haim H., Noor Hasmini AbdulGhani (2014). Direct and Indirect Effects of Product Innovation and Product Quality on Brand Image: Empirical Evidence from Automotive Industry. International Journal of Scientific and Research Publications, 4(11).

Jaafar, Siti N., Pan Ein Lalp, Mohaini, M. (2012). Consumers' Perception, Attitude, and Purchase Intention towards Private Label Food Products in Malaysia. Asian Journal of Business and Management Science, 2(8), pp. 73-90.

Kanagal, Nagasimha G. (2015). Innovation and Product Innovation in Marketing Strategy. Journal of Management and Marketing Research, 18.

Kapferer, J. N. (2008). The New Strategic Brand Management: Creating and Sustaining Brand Equity Long Term. London and Philadelphia. Kogan Page.

Keller, Kevin Lane, (2013). Strategic Brand Management: Building, Measuring, and Managing Brand Equity, Fourth Edition. Pearson Education Limited, USA.

Khan, N., Syed Hamed R. R, Hong Yong Hoe, Tan Booi C. (2015). Causal Relationship among Dimention of Consumer-Based Brand Equity and Purchase Intention. International Journal of Business and Management,10(1), pp. 172-181.

Kolbl, Ž., Konečnik Ruzzier, M., Kolar, T. (2015). Brand Revitalization: Don't Let Your Brand Turn into Sleepyheads. Central European Business Review, 4(2), pp. 5-11.

Kotler, Philip. (2003). Marketing Management. Eleventh Edition. New Jersey: Pearson Education International.

Kotler, Philip. (2007). Prinsip-Prinsip Pemasaran. Jakarta: Erlangga

Liljander, Veronica, Pia Polsa, Allard Van R.(2009). Modelling consumer responses to an apparel store brand: Store image as a risk reducer. Journal of Retailing and Consumer Services, 16(4), pp. 281-290.
Liu, C. M, Lin, K.W., Huang, C.J, (2014). Effects of product development on operating performance in textile industry. Anthropologist, 17(1), pp. 157-163.

Schiffman, Leon C., and Leslie Lazar Kanuk. (2007). Consumer Behaviour, $9^{\text {th }}$ edition. New Jersey: Pearson Prentice Hall.

Schiffman, Lazar Kanuk, in collaboration with Joseph Wisenblit. (2010). Consumer Behaviour. Tenth Edition. Global Edition. New Jersey: Patience Hall International, Inc.

Shah, Syed, S. H., Jabran Aziz, Ahsan Raza Jaffari, Sidra Waris, Wasiq Ejaz, Maira Fatimah, dan Syed Kamran Sherazi. (2012). The Impact of Brands on Consumer Purchase Intention. Asian Journal of Business Management, 4(2), pp. 105110.

Shiau, Horng-Cherng, (2014).The Impact of Product Innovation on Behavior Intention: The Measurement of the Mediating Effect of the Brand Image of Japanese Anime Dolls. Anthropologist, 17(3), pp. 777-788.

Sugiyono. (2010). Metode Penelitian Bisnis.Bandung: Alfabeta.

Suroso, Bayu, H., Sri Setyo Iriani, (2014). Pengaruh Inovasi Produk dan Harga terhadap Minat Beli Mie Sedaap Cup.Jurnal Ilmu Manajemen, Vol. 2(4), p. 1174-1185.

Thomas, Sunil. Kohli, Chiranjeev. (2009). A Brand is Forever! A Framework for Revitalizing Declining and Dead Brands. Business Horizons, 52, pp. 377-386.

Uliana, Dina, (2012). Pengaruh Inovasi Produk terhadap Purchase Intention: Studi pada Starbucks VIA. Jakarta: Universitas Indonesia.

Wang, Ya-Hui, Cing-Fen Tsai (2014).The Relationship between Brand Image and Purchase Intention: Evidence from Award Winning Mutual Funds. The International Journal of Business and Finance Research, 8(2).

Zeithaml, Valarie A. (1988). Consumer Perception of Price, Quality, and Value: A Means End Model and Synthesis of Evidence. Journal of Marketing, 52, pp. 2-22. 